\title{
On Motivation to Apply ODL in Adult Teachers' Education
}

\author{
Athanasis KAROULIS \\ Lyceum "Nikos Kazantzakis" \\ Norikerstr. 19/B2-12, 90402 Nuremberg, Germany \\ e-mail: athanasis@karoulis.gr
}

Received: January 2011

\begin{abstract}
This paper investigates the motivation of teachers of primary education to be trained by means of ODL (Open and Distance Learning). The survey took place during a professional training period and aimed to investigate initially the awareness of the teachers as regards the possibility to apply an ODL-model for this training, and secondly their estimations for the success of such an approach. Those questions are however considered through a motivational perspective, as the ARCS model of motivation expresses it. Results showed that a percentage of $20 \%$ of the teachers were not aware of the potential of a distance learning in general, while the rest of them appeared to be motivated to participate, yet they showed some hesitation for the outcomes of this "new" educational method.
\end{abstract}

Keywords: open and distance learning, ODL, adult education, teachers' education, motivation.

\section{Introduction}

This survey has been performed during a large-scale training for teachers of primary education. Discussions between teachers and author showed dissatisfaction for the expense of their program, as they were asked to attend the training after normal working hours. It was obvious that there was a violation of some basics of adult education, so the idea was born to investigate the possible acceptance by the teachers of an Open and Distance Learning (ODL model for this training, as it is known that ODL can successfully confront problems of Adult Education. In subsequent conversations, this question was further analyzed into two parameters: initially to how far teachers were aware of the potential of ODL in such cases, and secondly whether they were convinced that it would result in gains similar to the traditional face to face approach. However, these questions demand a broad survey design, so only one survey parameter has been chosen to be investigated, the parameter of motivation. In other words, main focus of this survey is whenever teachers of primary education are motivated to follow a distance learning approach for such a professional training, both as to the experience of the participation as well as for the expected outcomes of the training.

To investigate the motivation the ARCS model by John Keller has been chosen, mainly because it analyzes motivation in 4 distinct parameters, which can easily be recorded and measured, as it will be described subsequently. 


\section{Theoretical Framework}

\subsection{The Training Program}

The training program aimed to upgrade the professional knowledge and skills of teachers of primary education to the contemporary working conditions and was performed nationwide during the past years. Many aspects have been discussed and taught, however central point was ICT literacy of employees, who mainly obtained their degrees ten or twenty years ago. The present study was performed during the lesson "Application of ICT in the classroom". As it is obvious, no ICT skills were taught at this lesson, but merely application techniques, constraints, benefits and challenges of ICT in the classroom was discussed and applied in relevant exercises. The survey per-se, at the end of the lectures was questionnaire based. However, participants were asked to consider the whole training program, not only this particular set of lessons, and it was explained to them that the survey concerned motivational factors. Scope of this study was to investigate in how far the participants were motivated to follow an open and distance learning approach for this professional training.

\subsection{Stimulus}

During some conversations with the adult teachers and now students, they showed a high dissatisfaction and disagreement to the applied training approach. However, not the whole spectrum of the "dissatisfaction parameters" could be investigated, so only the motivational factor has been chosen and is taken into consideration in this work. Scope of the research was to investigate in how far teachers were aware that such a professional training could be delivered over distance, if they would participate in such a program and if they predicted the outcomes of this approach to be satisfactorily.

\subsection{The ARCS Model}

Motivation has been defined and analyzed by many researchers. The motivational approach followed in this study adheres to the four-factor-theory (ARCS model), stated initially by Keller (1983) and elaborated later in Keller and Kopp (1987) and Keller (1998). A contemporary Internet source with detailed analytical description of the model and the theoretical background can be found at the official site at http: / / www . arcsmodel. com/home. htm or a more concise one at the Penn State University (2006). According to this researcher, motivation can be analyzed into four distinct factors:

Attention (Interest \& curiosity) refers to whether the learner's curiosity is aroused and whether this arousal is sustained appropriately over time. This factor can be described in terms of:

- Perceptual Arousal. Gain and maintain student attention by the use of novel, surprising, incongruous, or uncertain events in instruction. 
- Inquiry Arousal. Stimulate information-seeking behavior by posing, or having the learner generate, questions or a problem to solve.

- Variability. Maintain student interest by varying the elements of instruction. Relevance refers to the learner's perception of personal need satisfaction in relation to the instruction, or whether a highly desired goal is perceived to be related to the instructional activity. This factor can be further described in terms of:

- Familiarity. Adapt instruction, use concrete language, use examples and concepts that are related to the learner's experience and values to help them integrate new knowledge.

- Goal Orientation. Provide statements or examples that present the objectives and utility of the instruction, and either present goals for accomplishment or have the learner define them.

- Motive Matching. Adapt by using teaching strategies that match the motive profiles of the students.

Confidence refers to the perceived likelihood of success, and the extend to which success is under learner control. This factor can be further described in terms of:

- Expectancy for Success. Make learners aware of performance requirements and evaluative criteria.

- Challenge Setting. Provide multiple achievement levels that allow learners to set personal goals or standards of accomplishment, and performance opportunities that allow them to experience success.

- Attribution Molding. Provide feedback that supports student ability and effort as the determinants of success.

Satisfaction \& outcomes refers to the combination of extrinsic rewards and intrinsic motivation, and whether these are compatible with the learner's anticipations. This factor can be further described in terms of:

- Natural Consequences. Provide opportunities to use newly acquired knowledge or skill in a real or simulated setting

- Positive Consequences. Provide feedback and reinforcements that will sustain the desired behavior

- Equity. Maintain consistent standards and consequences for task accomplishment.

\section{Survey Design and Application}

To investigate the four motivational parameters, the questionnaire-based survey has been chosen, mainly due to the large number of participants. However, interviews formal and informal took place continuously, in an attempt to comprehend and clarify deeper concepts and reasoning, as for example the refusal to participate in the survey.

\subsection{Subjects}

402 subjects participated in 21 classes, dispersed in 12 cities and the questioning period lasted more than 2 years, namely the period of the training. Focus of the study is the pa- 
rameter of motivation as perceived by the participants, being all adults and involved in a professional developed training program. A total of 326 adult teachers answered all questions, thus providing valid data for this work. They were volunteers, yet "captured", in the sense that this training was considered a "must" for their professional development. It aimed to upgrade the knowledge of teachers of primary education in all scientific aspects of their profession, including new didactical approaches, advances in science education and literacy in ICT. Thus, it can be argued that they had good reasons to participate in the program.

The subjects who refused to answer this part of the questionnaire were encouraged immediately in an open conversation, in order to clarify their refuse to answer. They all gave the same explanation: "Distance Learning is a term very "cloudy" to me. I don't know what it is exactly; neither do I know its potential; so I cannot answer any questions on it. Besides, we have little or not at all formal information on this aspect, and nowhere in our working space is it applied, so as for us to come in contact with this educational approach ..."

A sample of 30 subjects is considered to be the minimum if the researcher(s) plans to apply some kind of statistical elaboration on the collected data (Cohen and Manion, 1994). Thus, the present sample of 326 finally participated subjects is adequate to elicit valid results.

In detail: initial $n=402$, not answered $=76(18.9 \%)$, final $n=326$.

\subsection{Instrumentation}

The questionnaire delivered to subjects consisted of 5 parts. The first 4 parts of the survey concerned the investigation of the participants' attitudes towards this professional training and are reported separately. Present study concerns only the 5th part of the questionnaire. It consisted of 4 questions, one for each motivational factor, and it is presented below. The subjects noted their assessment on a 7-graded Likert scale, by means of bipolar semantic differentiated expressions.

Part E: An alternative approach (Don't answer, if you think you can't!)

1. The idea to be trained through Distance Learning would provoke any interest in you?
(1)
(2)
(3)
(4)
(5)
(6)
No, not at all ...
It would be extremely interesting!

2. Do you consider such an approach to be relevant to your personality?
(1)
(2)
(3)
(4)
(5)
(6)
No, it doesn't fit me...
Yes, it fits me perfectly!

3. Do you believe you could successful complete such a training?
(1)
(2)
(3)
(4)
(5)
(6)
I would fail ..
Of course, no big deal!

4. Would you feel satisfaction to participate in such a program?
(1)
(2)
(3)
(4)
(5)
(6)
Unpleasant idea...
It would be a pleasant experience... 


\subsection{Execution and Data Validation}

The answering of this part of the questionnaire took place during a pause of the instruction. Its completion took an average of 5-6 minutes. As the participation in the survey was completely voluntarily, the collected data was considered reasonable and no exception of data was made from the elaboration.

\section{Data Elaboration}

4.1. Descriptive Statistics

Table 1

Central tendency indicators

\begin{tabular}{lllll}
\hline $\mathrm{n}=326$ & Mean & Median & Mode & St. dev. \\
\hline Q1 & 4.60 & 5.00 & 6 & 1.853 \\
Q2 & 4.07 & 4.00 & 5 & 1.647 \\
Q3 & 4.17 & 5.00 & 5 & 1.475 \\
Q4 & 4.44 & 5.00 & 6 & 1.768 \\
\hline
\end{tabular}

From the descriptives table one can infer that all three indicators, mean, median and mode are not particular high (around 4.5 in a 7-grades scale), yet they provide certain unanimity, shown by the low standard deviation (below 1.85). In Fig. 1 this unanimity is visualized: means values (first columns) between 4 and 4.6 and standard deviation (last columns) below 2 .

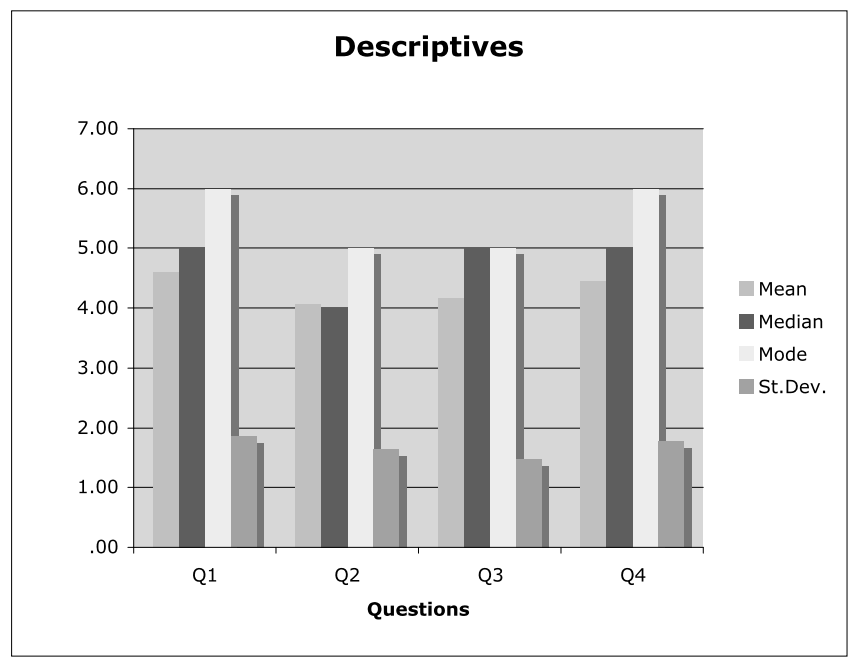

Fig. 1. Bars for central tendency indicators. 


\subsection{Inferential Statistics}

The evolving question is now whenever this unanimity between the four questions (for attention, relevance, confidence and satisfaction) is statistical significant. To investigate it, the correlation and covariance matrixes were calculated, as well as an analysis of variance (ANOVA) for all 4 factors was performed.

In the correlation matrix one can see high correlations, close to 1 (maximum, absolute correlation). In the covariance matrix respectively one can see very low variation of opinions (between 2 and 3, maximum being at infinite). Despite the obviousness of those matrixes, an ANOVA has also been performed.

Interesting point in the above table is the p-value (0.00), meaning an almost flawless unanimity of all four motivational factors of attention, relevance, confidence and satisfaction.

\subsection{Statistical Findings}

Those findings, of the statistical unanimity of the four factors can be interpreted in practice as a support to consider "motivation" as a whole for the rest of this work. In other

Table 2

Correlation (a) and covariance (b) matrixes

\begin{tabular}{|c|c|c|c|c|}
\hline & E.1 & E. 2 & E. 3 & E.4 \\
\hline E. 1 & 1.00 & & & \\
\hline E. 2 & 0.75 & 1.00 & & \\
\hline E. 3 & 0.66 & 0.71 & 1.00 & \\
\hline E. 4 & 0.73 & 0.70 & 0.63 & 1.00 \\
\hline
\end{tabular}

(a)

\begin{tabular}{lllll}
\hline E.1 & E.2 & E.3 & E.4 & \\
\hline E.1 & 3.42 & & & \\
E.2 & 2.27 & 2.70 & & \\
E.3 & 1.80 & 1.72 & 2.17 & \\
E.4 & 2.40 & 2.04 & 1.65 & 3.12 \\
\hline
\end{tabular}

(b)

Table 3

Analysis of variance (ANOVA)

\begin{tabular}{lllll}
\hline $\begin{array}{l}\text { ANOVA: Single Factor } \\
\text { SUMMARY }\end{array}$ & & & & \\
\hline Groups & Count & Sum & Average & Variance \\
\hline E.1 & 326 & 1501 & 4.60 & 3.43 \\
E.2 & 326 & 1327 & 4.07 & 2.71 \\
E.3 & 326 & 1361 & 4.17 & 2.18 \\
E.4 & 326 & 1448 & 4.44 & 3.13 \\
\hline
\end{tabular}

\begin{tabular}{|c|c|c|c|c|c|c|}
\hline Source of Variation & $\mathrm{SS}$ & $\mathrm{df}$ & MS & $F$ & $\mathrm{P}$-value & F crit \\
\hline Between Groups & 58.32 & 3.00 & 19.44 & 6.79 & 0.00 & 2.61 \\
\hline Within Groups & 3720.76 & 1300.00 & 2.86 & & & \\
\hline Total & 3779.08 & 1303.00 & & & & \\
\hline
\end{tabular}


words, there is no more need to analyze motivation in its 4 factors and study each one separately; it is obvious that the term "motivation" is accurately depicted by the synergy of all 4 factors.

\subsection{A Posteriori Research}

Soon by the completion of the first few questionnaires it was made apparent that a great number of participants refused to fill out the 5th part of it. So, an "a posteriori" approach was set up, namely to ask as many subject as possible for the reason for this "neglecting". The approach here was short interviews, aiming to clarify the reasons for this, as deep as it was possible. Of course not all refusing subjects could be interviewed, mainly because to the time needed for every interview and the consequent writing down of the opinions. In addition, no statistics were applied in that part of the data, but rather only the initial parts of a usual qualitative elaboration: grouping, counting and summarizing of the opinions. An estimation of the interviewed subjects is about $50 \%$ (half of them). Findings showed that in a percentage of $75 \%$ reasoning could be summarized as: "ODL is a term very vague to me. Of course I know about it, but not in details. I am not aware of application possibilities, nor of its potential, so I cannot answer. Further on, we have little formal information on this aspect, and we don't see it to be applied somewhere in our professional space, so we lack relevant experiences ..." A further attempt to go deeper in reasoning leaded to the fact of its absence in formal education (those teachers were employees in primary formal education), the final conclusion of many of the interviews being: "it's not foreseen, nor applied, nor allowed!..."

\section{Results and Discussion}

First important finding was the number of the subjects who refused to complete the questionnaire, because they were not aware of the potential ODL has to offer, according to their stating. They were 76 out of a total of 402 , which means a $18.9 \%$. In other words, about one fifth of the questioned teachers were not aware on the potential of one of the most "trendy" contemporary educational methodologies. One could argue that this percentage is normal, as their own answers give the explanation of absence from their close professional environment.

Second finding is the almost absolute unanimity, as the statistical elaboration showed (correlation and covariance matrixes). This could be explained however by the homogeneity of the subjects. In other words, the percentages of the teachers who are actually aware of ODL seem to be on the same stage of awareness.

Third finding is the relative low confidence in ODL (statistically at 4.5), closer to the middle of the scale (3.5) than to the highest value (7), with almost unanimity. It gave the impression that, on one hand they are aware of ODL, but on the other hand they are "limited optimistic", refusing to give high values to almost no one of the motivational factors. 
Taking into consideration their own reasoning, one can argue that those hesitations, despite the obvious motivation, are really due to the small grade of pervasion of ODL in formal primary education. It is known that ODL plays nowadays a significant role in ternary education; however, participants in this survey seem to adhere to the opinion that its application in primary education has been by so far seriously neglected.

\section{Restrictions and Validity Threats}

One validity threat of this study could be implemented in the structure of the questionnaire. It consisted of 5 parts; the four first parts investigated another aspect, namely the motivation for the undergoing training, while only the fifth part (which is presented here) investigated the aspect of "training through ODL". So, it is plausible that some subjects considered this part as irrelevant to the rest of the survey and neglected to answer it. It is not known which percentage of the subjects might have thought this way, the subsequent interviews did not speculate on it.

Another validity threat could be the small number of questions in this part of the questionnaire; however, the large number of participants counterbalances this. Further on, the small questions number could be seen as actually provoking participation. In other words, those who didn't answer were probably those who really didn't know what to answer, and not because they were disappointed by the size of the questionnaire.

As regards the $80 \%$ of the subjects who answered the questions, it is not known their familiarity grade with ODL. They could simply "have heard something" and answered based on this, or they could have already applied (or participated at) some lessons over distance up to a full application of ODL. This parameter was not foreseen in this survey and is not considered in findings and results.

Finally, as it is obvious, the findings of this study concern the environment (country, educational settings, teachers' level of proficiency etc) where the survey was performed and cannot be generalized without hesitation. Even the generalization to similar environments is risky, as "Education" is very sensitive to its particular applications and instructional methodologies. So, this study depicts only the described framework.

\section{Conclusion}

In concluding the above, one can argue that teachers of primary education in the presented framework and in a percentage up to $20 \%$ are not really aware on ODL and its potential, while the "aware" ones seem on one hand to be motivated to follow a professional training program delivered over distance, while on the other hand they have some hesitations as regards the absence of ODL applications in their close professional environment which could serve as biome and source of experience. 


\section{References}

Cohen, L., Manion, L. (1994). Research Methods in Education. London, Routledge.

Keller, J.M. (1983). Motivational design of instruction. In: Reigeluth C.M. (Ed.), Instructional Design Theories and Models: An Overview of Their Current Status. New York, Lawrence Erlbaum, 383-434.

Keller, J.M. (1998). Using the ARCS process in CBI and distance education. In: M. Theall (Ed.), Motivation in Teaching and Learning: New Directions for Teaching and Learning. San Francisco, Jossey-Bass.

Keller, J.M., Kopp, T.W. (1987). Application of the ARCS model to motivational design. In: C.M. Reigeluth (Ed.), Instructional Theories in Action: Lessons Illustrating Selected Theories. New York, Lawrence Erlbaum Publishers, 289-320.

Penn State University (2009). http: / / ide.ed.psu. edu/idde/ARCS.htm (retrieved 28 Nov 2009).

A. Karoulis has a BSc in mathematics, a MSc in information systems, a MSc in education and $\mathrm{PhD}$ in informatics, in the domain of human-computer interaction. He has more than 60 publications and announcements in journals and conferences. He is author of two books and co-author of another five and he has managed or participated in more than 15 national and international projects. His scientific interests are in the domains of educational technologies, distance learning, human-computer interaction, software engineering and information systems.

\section{Atvirojo nuotolinio mokymo taikymo suaugusiems mokytojams rengti motyvai}

\section{Anthanasis KAROULIS}

Šiame straipsnyje nagrinèjama pradinio ugdymo mokytojų motyvacija mokytis naudojant atviraji nuotolini mokymą. Mokytoju apklausa vyko profesinio mokymo laikotarpiu ir buvo siekiama ištirti mokytoju požiūrị i galimybę taikyti atvirojo nuotolinio mokymo modeli bei apskaičiuoti tokio metodo pasisekimą. Apklausos klausimai formuluoti taip, kad išreikštu motyvacines perspektyvas, kaip ir ARCS modelyje (ši modelį sudaro keturi žingsniai, kuriais siekiama paskatinti ir palaikyti motyvaciją mokytis: dèmesys, aktualumas, pasitikejjimas, pasitenkinimas). Rezultatai parodè, kad 20 proc. mokytoju nežinojo apie nuotolinio mokymosi galimybes, likusi dalis buvo motyvuota dalyvauti, tačiau jie išsakè kai kurias abejones dèl šio „naujo“ mokymo metodo rezultatų. 